\title{
LEARNING BY DOING: \\ THE SOCIOLOGICAL APPROACH WITHIN \\ EDUCATION FOR A SUSTAINABLE DEVELOPMENT
}

\section{Katarzyna Iwińska*, Marta Sałkowska**}

\begin{abstract}
The objective of this article is to critically and reflectively describe the idea of education for sustainable development (ESD) in the context of higher education. We tackle the possibilities of implementation some useful skills and competences in the process of students' sociological training. Firstly, the concept of ESD is discussed and its framework is presented focusing on the social aspect of sustainable development. Then we introduce a link between sociological training and ESD, as well as the challenges faced by the academy, academic teachers and students. We evaluate the case of the field research (vocational) sociological training for students and discuss the findings in the context of ESD. We present how aspects of Participatory Action Research (PAR) can be used in teaching social competences useful from the perspective of young people. We focus on competences obtained by students - professional as well as interpersonal or even personal. With such competences students can further deepen their awareness of sustainability and inclusion, policy and decision making processes.
\end{abstract}

Keywords: education for sustainable development (ESD), sociological training, competences, local communities, participatory action research (PAR)

*Ph.D., Katarzyna Iwińska, Collegium Civitas, Warsaw, Poland, mail: katarzyna.iwinska@civitas.edu.pl, ORCID: https://orcid.org/0000-0002-7337-915X

**Ph.D., Marta Sałkowska, Collegium Civitas, Warsaw, Poland, mail: marta.salkowska@civitas.edu.pl, ORCID: https://orcid.org/0000-0002-8011-8214 
The objective of this article is to critically and reflectively describe the concept of education for sustainable development (ESD) in the context of higher education, specifically in social sciences. Thus, it discusses the potential role and importance of sociological education as regards the implementation of the concept of sustainability.

We also consider the wider context - the dominating model of relations between students and academic teachers, as well as, relations between the university (as a higher education institution) and society (functions of university), particularly the interaction between students, academics and society.

Since the debate about sustainable development is a critical answer to the neoliberal narrative which permeates various fields, including the field of education (Kopnina 2014; Kopnina, Cherniak 2016; Gruenewald 2008; Freire 2005; Sterling 2014), the reflections on education for sustainable development are not limited to the need to change the university curriculum or the development of training methods.

Thus, the conclusions formulated within these frameworks pertain both to the content and to the methods of education, as well as to the (re-)definition of social roles and the relationship between lecturer/ academic and student, and finally to the aims and functioning of the university as a social institution.

In addition, we prove that ESD can show the value and role of "public sociologists", i.e. those actively working in the world and aware of the "diversity and complexity" of processes, who also implement the idea of bringing balance to social processes through civic engagement (Burawoy 2004). Therefore, consistent application of the idea of education for sustainable development has substantial reformatory potential in all of these areas. 
Education for sustainable development

The idea of sustainable development (SD), which has been defined as "(...) development that meets the needs of the present without compromising theability of future generations to meet their own needs" (UN 1987), arose primarily as a result of the insistence of scientists and politicians in international assemblies on cooperation against climate change. Today, we call it rather climate catastrophe and try to incorporate SD education related to excessive population growth, problems with satisfying the basic needs of an increasingly larger global population, as well as environmental and socioeconomic changes ${ }^{1}$. The most common definition of SD is linked to climate changes and so called "green ideology".

However, the question of "sustainability" does not pertain solely to the natural environment, but also to the social and cultural context, both at the global level and at the very local (even individual) one. It is also important to consider ESD as a decision-making process where a tripleperspective (social, economic and environmental) is taken. The awareness of the complexity and understanding of the importance of various trade-offs between these three element s is crucial in education.

The concept of SD itself has many definitions, and over the last 30 years, it has been the subject of many different interpretations and analyses ${ }^{2}$. However, although the term is so much rooted in economic visions and environmental problems, we claim the social aspects are undermined, specifically the meaning and significance of sustainability for various individuals in a defined situational context.

Our aim is to translate the concept (rooted more in natural sciences) into praxis (Bourdieu 1990, p. 54) and practical actions (Loeber 2004;

\footnotetext{
1 Italy is the first country to introduce climate education as obligatory course. See: Henebery 2019.

${ }^{2}$ In the words of Raco (2005, p. 329), sustainable development is a "chameleon" discourse that has been (re)interpreted and used by many interest groups to legitimize and justify a range of often contradictory demands.
} 
Loeber et al. 2009, p. 84). Furthermore, since this concept is normative in character and may offer desirable courses of action, it is assumed that thanks to processes of learning, awareness and inclusion of different groups, it is possible to work out a balance between different actions that are considered desirable for the future. For this reason, attention is increasingly being drawn to the multi-dimensional character of sustainability, especially regarding Education for Sustainable Development (ESD).

In 2005, the Director-General of UNESCO, Koichiro Matsuura, announced the beginning of the Decade of Education for Sustainable Development 2005-2014, and presented a strategy of actions to be implemented in order to develop such education with a global perspective. The aim of the strategy was to identify significant changes in the education process, which should contribute to the implementation of that strategy in accordance with the idea of sustainable development.

In Poland, this decade found little resonance in educator circles (neither private nor public), and the issue of sustainability was not included as an obligatory part in the curriculum at any level of education. Some non-governmental organizations, like the Center for Civic Education announced temporary training and some universities have opened post-graduate courses focusing on SD (based on WISE project output 1$)^{3}$.

Besides the new forms of curriculum, it is possible to incorporate the SD topics in all courses, also for humanities and social sciences (HSS), as as ESD aims at developing competencies that empower people to take informed and responsible decisions for a sustainable future (UNESCO 2002; UNESCO 2016; Wals 2015) and has been already

3 The project Widening Interdisciplinary Sustainability Education (WISE), funded by Erasmus Plus in 20162017, resulted in many analyses as well as practical guides/lesson plans. The report mentioned here is entitled Overview Discipline Approach: Education in Comparative Analysis and is available online: http://wiseproject.info/wp-content/uploads/2016/04/WISE_1.pdf [November 4, 2019]. 
adapted as an educational approach worldwide (see also Činčera, Aspengren 2018).

Rittel \&Webber (1973) connected the environmental problems with the social dimensions of diagnosing, planning and acting towards them and used the term "wicked problems" to define its complexity (Iwińska, J ones 2018). That is why there is a great need towards a new form of education that should be more focused on competences (Wiek et al. 2011; Rieckmann 2015) than on strict (environmental or scientific) knowledge.

Additionally, it is worth mentioning, that young people today have to face not only the consequences of global environmental changes, but also the complex associated sociopolitical problems (Sund, Lysgaard 2013). OECD reports indicate that growing social inequality is a particularly dangerous trend (Schäfer 2012; OECD 2011; OECD 2015). In our opinion, the education that is part of a sociology course should be designed to better engage students, give them more opportunities to experience the role of a sociologist and help them feel and act as agents, when solving important problems in the world around them. This requirement is also a conclusion from current diagnoses regarding the contemporary generation, which is not only referred to as "generation $\mathrm{X}, \mathrm{Y}$ or MTV", but also points to a particular challenge faced by the new generation of young people, the so-called Generation R (McCrindle 2003).

Due to lightning-fast civilizational and environmental changes, which have an impact on every human being on the local and global levels, the generation that is now beginning its education process is supposed to be the so-called "responsible generation", or Generation R ("R for responsibility") (Mueller et al. 2014).

According to this concept (Ibidem, p. 12), the worldview of Generation $\mathrm{R}$ will be rooted in the idea of sustainable development, which means that these young people must have first and foremost 
a broader understanding of social phenomena and of their social, cultural and historical implications. In comparison to earlier generations, the members of Generation R should also be more focused on their own relationships with others (in the world).

What is more, some researchers think that we are now witnessing a new social revolution, which is a "sustainability revolution", also called sustainalization (see: Ayers 2011; Burns 2012; Edwards 2005). As more and more effort is being made to shape a new sustainable order at the micro-, meso- and macro-level, it can be compared to the industrial revolution in the previous century (Burns 2012, pp. 22-23).

The arguments presented above are only a small part of the reasoning for a change in educational systems in order to focus on competences that allow new generations to better manage the world system (Wiek et al. 2011; Činčera et. al. 2019). We now turn to the teaching of sociology.

\section{A challenge for teaching sociology}

The challenges faced by the university and by academic staff constitute the starting point for our reflections. There is an ongoing debate which we are witnessing and, occasionally, actively participating in - on the state of university education and the role played by this age-old institution.

Commodification of the university (Ball 2012; Willmott 1995), or more broadly of education, has been diagnosed as one of the causes of the current problems. In consequence, the seemingly neutral categories of management effectiveness and efficiency dominate the discourse on education (Szkudlarek 2008).

"Traditional university values are being replaced by the rules of the market game. This is true both for research (...) and for educational majors and specialties, which are dictated by the labor market, while 
eligibility requirements formulated by the various ministries and professional associations serve as the basis for study plans and programs. In a way, education and scientific research are becoming a field of production" (Czerepaniak-Walczak 2013, p. 11; Miller 2010).

This is the context in which the daily interactions between academic teachers and students take place. Obviously, this context, which has been termed "critical", has a significant impact on the shape and course of these interactions.

When faculty members - academic teachers - create curricula at universities, they frequently find it difficult to reconcile the differing expectations of students and employers, while simultaneously fulfilling the requirements imposed by the Ministry of Science and Higher Education. At the same time, "rational management" must remain a constant priority, since attempts to adapt education to market demands constitute just one aspect of a broader process known as economization of education.

Simultaneously, as Czerepaniak-Walczak (2013) wrote, in such a system students are treated as products - they are shaped according to guidelines issued by prospective employers and by the government administration with the aim of enabling them to perform specific vocational roles. It is a paradox that on the grounds of the idea of pluralism and freedom as important values promoted by neoliberalism, the education process emphasizes students' subjectivity (Kopnina 2014).

More precisely, they are to be "subject-products" - active and enterprising in the labour market, but also good consumers of educational services. As a result, the university loses its traditional functions, since it ceases to shape the development of critical and independent thinking, and does not require its students to exhibit this ability. In turn, the students themselves expect that higher education will make them an attractive "commodity" in the labour market, and 
treat studying as a way to acquire the specific skills and competences required by employers ${ }^{4}$ (Ball 2012; Barret 2011; Cuthbert 2010; Shumar 1997).

This picture of relations at the university is radically different from the proposal formulated by Michael Burawoy (2009; 2012), according to whom an academic teacher acts as a public sociologist. His audience is made up of students who come to university with a wealth of experience. The teacher's task is to accompany them and support them in the analysis and development of this experience. The ability to continuously research and reinterpret life experience and researchers' use of this experience is essentially the basis of "good work" in the social sciences (Mills 2007).

Thus, academic support should help students better understand what Burawoy calls "historical and social contexts that have made them who they are" (Burawoy 2004, p. 9). They should better understand their role as sociologists, and ought to actively create their professional identity, utilizing knowledge acquired during university studies, as well as processing their experience and abilities. According to this thinking, academic education should involve multilateral dialogue: teachers with students, students with their own experiences and with other students, and finally, students with the non-academic community (or audience).

According to Burawoy, this last dialogue can best be achieved during field vocational training, which creates an opportunity to better understand the functioning of individuals in the social world, as well as to better comprehend contexts and one's own capacity for action. This, in turn, makes it easier to function effectively under conditions of constant change and postmodern transformations.

4 Analysis results presented by Wroczyńska (2013, p. 270) appear to confirm this thesis, since they show that “(...) modern students expect higher education to implement educational objectives of the Bologna process". 
Furthermore, field vocational training is not only a way to test research abilities in practice, but also a chance for students to become acquainted with social reality and an opportunity to sensitize them to diversity. This is important because, as Wright Mills (2007) has noted, one of the aims of the social sciences is to understand human diversity. A broader look at Burawoy's postulates and the image of the individual human being that constitutes their basis makes it possible to see their affinity with the concept where the individual is entangled in the process of creating and recreating society (Berger, Luckman 1983; Giddens 2003; Sztompka 1999).

As an agent, the individual participates in constant, internalized "dialogue" with the surrounding social world, created by other people and their groups. The social context of action is a stimulus for selfreflection on the individual's "being in the world"5.

At the same time, the response of the individual who is subjected to constant social impact allow both that individual and the social milieu to continue existing (Archer 1995). Such a perspective makes it possible to emphasize the role of the above-mentioned educational processes, or - more broadly - processes of socialization that occur in the context of higher education.

Thus, in the course of these processes individuals not only become sensitized to social diversity or learn to notice it, but also reciprocally impact that process and the context in which it takes place. Ultimately, they also become more conscious subjects of public/ social life. In other words, when individuals assume the roles of students, sociologists or

\footnotetext{
5 In the course of this process, it is possible to "become accustomed" to the given social role or roles, or to "become displaced" from them. In other words, the social identity based on the given role shapes itself. Thus, identity is the individual's reflexive projection or self-reference to social reality. This approach leads to a dynamic conception of identity, in which identity is the subject's conscious act, based on understanding and interpretation.
} 
social researchers, they can have a permanent impact on the reality in which they live, by either changing or consolidating it 6 .

The above characteristics of education, described here in a fairly general manner, can provide valuable guidance on coping not only with the challenges of civilization, but also with the challenges faced by universities. In our opinion, they have particular significance for education in the field of the social sciences, including sociology.

However, reflections on ESD are not limited to the need to change the university curriculum or the development of training methods, because the debate about sustainable development is a critical answer to the neoliberal narrative which permeates various fields, including the field of education (Kopnina 2014).

On the other hand Wals et al. (2012) compares ESD with communitybased programmes that draw on the concept of social learning in which community members learn from one another in the process of seeking resilience and better competences for the future.

Researching local communities as implementation of aspects of ESD Sterling and Maxey (2013, p. 3) diagnose the existence of a significant gap between the observed agenda of higher education and ESD. This provokes a question about the ways that could help bridge that gap. In this part we show how a university course involving local field research not only helped students in learning and understanding the skills and theory on research methods, but also inspired them (and us - academic teachers) to see the world from a different, broader perspective.

The field research conducted within local communities in the Silesian Voivodeship gave students the opportunity to notice connections and networks of different groups, interests and trade-offs, conflicts, social inequalities and civic engagement. Maintaining a field

\footnotetext{
${ }^{6}$ This has further consequences for the concept of the university's role. Many parties are involved in such "work" on identity, and it can occur within the scope of the university's activities. In such cases, the university's mission of enlightenment ceases to be its sole purpose, and the knowledge produced there becomes available to the society at large (cf. Gdula 2010, p. 226).
} 
presence requires paying attention to different perspectives and social needs. It also necessitates awareness of social, cultural and economic diversity.

Moreover, field trips are a chance for students to view the world in an interdisciplinary manner and to change their attitudes, as well as an opportunity for self-development, whereas from the perspective of academic staff they perfectly embody the andragogical principle of "learning by doing" through the cooperation and commitment of theentire team. For the university, in turn, they are a way of implementing the seven principles of education for sustainable development formulated as part of the UNESCO strategy (Weinstein-Fitzgerald 1999; Horyń, Maciejewski 2007).

The example of field research with students (vocational training)

Our reflections on implementing the concept of education for sustainable development are based on experiences associated with vocational training for students in the Mykanów community?

Researchers and students from Collegium Civitas carried out two social research projects in the Mykanów commune at the initiative of, and in cooperation with, the local cultural center (Gminny Ośrodek Kultury, GOK) in Mykanów.

\footnotetext{
7 In Collegium Civitas, the important role of so-called "research study visits" in shaping the professional skills and (civic) attitudes of sociology students has been emphasized ever since the founding of the university. Field vocational training has been discontinued for various reasons, and student vocational training at potential workplaces has taken its place. Such a strategy has been adopted largely due to the unique situation of Collegium Civitas, a non-public institution which must (perhaps to an even greater extent than public universities) take into account the expectations and needs of its students, while ensuring high quality of the classes offered. This situation is worth noting regarding the description of the group of students who participated in the field research camp. The first research project (2011) was organized as a part of elective classes (i.e. participation was voluntary). The second research field work, along with the preparatory classes (2015), was mandatory for most of the group. However, it was precisely these students who didn't want to study sociology as such, but rather the specialty associated with marketing, advertising and new media. Thus, they weren't necessarily interested in sociology classes, much less in mandatory research. Few participants had actually chosen the course.
} 
The first study took place in 2011 and spanned the communities of six small rural administrative units (sołectwo): Wierzchowisko, Lubojenka, Radostków-Wieś and Radostków-Kolonia (Mykanów commune), Widzów (Kruszyna commune), Zawada (Kłomnice commune) and Dąbrowa Zielona (Dąbrowa Zielona commune). Its goal was to diagnose and search for social potential, as well as to describe local activity in selected localities. The idea was that sociology students would carry out research in close cooperation with local cultural animators, local leaders and with the village residents. We returned to Mykanów with a team of students after 4 years (in 2015).

The study covered the entire Mykanów community. The research topic was the sociocultural and educational activity of rural sites. The main goal was to develop, using participatory research design (in cooperation with some of the residents), a Strategy for Sociocultural Development of the Residents of the Mykanów Community for theyears 2016-2020. Both studies were not originally designed within the scope of the ESD. It was later when we reflected on our research activities and the ways we involve students and realized we were implementing it.

Both studies were based on cooperation - first with the local cultural institution that had initiated the project, then with thelocal people, e.g. during a series of participatory workshops and meetings organized in rural cultural centres. Our goal was not to gather academic knowledge but rather "practical knowledge".

We attempted to gain both: methodological practice and the knowledge that would be useful to the local community. Instead of applied research, where the researchers (often newcomers to the community) formulate the topic and the problem, and then propose solutions based on their knowledge, professional competences and experience (Greenwood 2012, p. 116), we chose to employ the methodology of participatory action research (PAR). PAR is based on a pragmatic approach to research, involves active participation of the 
studied community and assumes that research results will subsequently be utilized in the life or work of community members (the subjects of the study) (Stringer 1996, p. xvi).

In the words of Kurt Lewin, a classic author and the main advocate of action research: "[t]he research needed for social practice can best be characterized as research for social management or social engineering. It is a type of action-research, a comparative research on the conditions and effects of various forms of social action, and research leading to social action. Research that produces nothing but books will not suffice" (Lewin 1946, pp. 202-203; see Lewin 2010).

However, as research-didactic staff, we were unable to carry out classic (complex) action research, which should entail the constant presence of researchers in the local community and their long-term involvement in its daily life, because of our numerous professional duties at the university, as well as logistic and financial constraints.

Thus, we attempted to find a solution that would involve joint engagement of researchers and students (adepts of sociology), as well as local associates. We wanted to conduct research not on people, but rather with people and for people (cf. Wyka 2004; Greenwood 2012), with limited possibilities of staying in the local community.

Furthermore, as researchers we wanted to maintain partnership relations with the local people. We did not wish to be perceived as "experts" or consultants from Warsaw who know better what is important and beneficial for the locals. We assumed that dialogue and learning from each other constitute the foundation for the entire research process, we practiced it and taught this principle to students.

In action research methodology, researchers act more as facilitators rather than scientists or experts. Their main task is to assist the people, in the case of these studies, the village residents, in defining problems and designing appropriate solutions (Wyka 2004, p. 60; Greenwood 2012, pp. 116-117). 
Thus, cooperation with all research subjects, i.e. the people around the GOK and interested residents, was of paramount importance to us. With this in mind, we cooperated with them step by step in defining the problems, working out the details of local "issues", designing subsequent stages of the project, opportunities for some solutions and ways of their implementation. Together, we planned the process of data collection and established the criteria for subject selection. Cooperation was necessary for both sides to actually become partners and take responsibility for their own actions. Such an approach made it possible to avoid a client-contractor relationship by engaging partners in joint realization of the given task, one important for both sides.

Because our study was to fulfill the additional function of practical research training for students of sociology, we also had to train them in using the "basic tools" of field research: gathering data by means of individual free interviews and questionnaires. This fact has important implications as regards implementing only selected postulates of action research. This perspective focuses on dialogical perception of the research process and the learning process between all parties (students, academics and local communities).

Lessons learned

The field vocational training was evaluated multiple times: the assessment was done through conversations directly after each day in the field site, analyzing short student notes and online evaluation questionnaires (available via the university's website). A mini focus group was also organized ${ }^{8}$ as well as face to face interviews after the field work. It gave researchers a lot of insights and new material to learn

\footnotetext{
${ }^{8}$ The students for whom both the course and the field vocational training had been elective rather than mandatory were invited to join this group. The aim was to find out what had motivated students to participate in these activities.
} 
about the effects of the research trips and about changes in students' attitudes 9 .

Students who had participated in the research process described multiple benefits from this experience, which can be divided into two categories. The first one involves the acquisition of professional competences associated with the profession of a sociologist (researcher), whereas the second one is more general in character and has to do with interpersonal competences. It is also linked to personal development ("T learned something about myself").

In answer to the question "What did you gain from participation in the project", participants mentioned all-around benefits. They declared that by participating in the study they acquired the skills to:

(1) overcome their own and others' reluctance,

(2) persuade others, and

(3) work as a team.

Students also drew attention to the factors that facilitate effective teamwork. Among other things, they mentioned: maturity (including age), a sense of duty and responsibility, honesty, lack of competition, task division according to competences, abilities and experience. They also noted the constructive character of a conflict situation that involves a common search for solutions, rather than rivalry. Thus, they saw the benefits of cooperation.

Students also mentioned benefits associated not so much with interpersonal competences, but rather with personal development, e.g.:

1. confidence - it turned out that despite the difficulties in convincing different people to participate in the study, it was ultimately possible to convince them, which gave students the feeling of an accomplishment (when the subject overcame his/ her reluctance and began to talk),

9 We will not describe in detail all the impressions and evaluations of the participants and the research camp, focusing instead on the ones associated with the concept of education for sustainable development. 
2. faith in themselves, in their own skills, increased self-esteem ("there is something at which I am not totally hopeless"),

3. the ability to cope with a difficult challenge (when "thrown in at the deep end").

Asked about the professional competences of a sociologist, participants said that "you have to experience it", i.e. learn through first-hand experience; participation in course activities (at the university) is not enough. These answers do not refer only to the ability to gather data, conduct interviews and surveys.

During the field research camp students found themselves in the role of actual researchers, and were perceived as such by the local community. Participation in the field research allowed them to encounter entirely different people and learn what those people think, what they feel - in other words, get to know others.

Some of the students changed or revised their opinion about the Polish rural areas. In their own words, it became significantly more positive: the rural areas proved much more interesting than expected ("Praga Południe [a district of Warsaw], where I live, is calmer than the countryside").

The opinions we collected also show that the camp participants gained more respect for people and for a variety of attitudes - "one should never despise (other) people - they are affected by different mechanisms and you have to understand that".

They also mentioned that it's one thing to know about diversity and to discuss it during seminars, but it's another thing to encounter it in a different setting than the one seen on a daily basis in a city with multiple universities. Thus, they learned to understand other people in the situations which those people find themselves, and to takeinto account local and individual contexts.

According to the students who participated in the vocational training, the sociologist's role is to be a "transmitter". Sociologists 
should broaden knowledge, show the causes of various human actions and help others understand them. Furthermore, it is their task to foresee trends and provide the tools for understanding the functioning of social groups or local communities. When conducting sociological research, it is necessary to induce people to answer as many questions as possible without causing irritation or annoyance.

Students also noticed that the presence of researchers in a local community gives rise to certain expectations and hopes, and that those researchers "really can change something in someone's life". According to them, the sociologist is able to maintain distance, which enables him/ her to see more and to view the local community from a different perspective. The participants were surprised by the differences between the interests of the researchers themselves and those of the study subjects. It turned out that the study subjects found the general questions, less important in regard to the study's goals, much more interesting, and showed the most readiness to answer them. The students were also surprised by the discrepancy between statistical data and data gathered in the field.

Particularly important in the context of the aims of education for sustainable development are those experiences of students which indicate "non-work" benefits. Obviously, the main objective of the vocational training was to improve professional skills in research. However, it is also extremely important for a social researcher to possess interpersonal skills, including the ability to adopt an open attitude towards others, to understand social diversity, as well as to establish contact and conduct interviews with various people.

From the perspective of education for sustainable development, it is also important to take responsibility for one's actions, both within the research team and within, or towards, the local community. Thanks to the vocational training in research, students learned to feel responsible for an important task, as well as for the broader community. Furthermore, 
they not only noticed their own change and development, but also understood that, with their own actions as sociologists, they can support other people in the processes of defining significant local problems and responding to them.

In accordance with the idea of education for sustainable development, the goal of the vocational training organized by us was not only to familiarize students with the "methodological tools of the sociologist", but to transmit a certain attitude towards the world welive in and show the importance of certain values, such as, cooperation when face with diversity, inclusion of groups, and engagement in public issues.

Additionally, it teaches reflexivity and shows the systemic consequences of action from the example of a small commune. We also wanted to enable young people to be more independent in their further activities and self-development. In regard to the postulates formulated in the UNESCO strategy, we emphasize that education through vocational training is certainly a way to increase the "sustainability" of students' knowledge, understanding, critical thinking and the ability to solve problems, since it takes place in daily life - both of the students (who are "thrown" into a new situation) and of the local community. This is one possible way of showing the problems associated with implementing the idea of sustainable development, and one possibility of experiencing them.

Traditional and reformatory sociology teaching

Sociology - as Adam Podgórecki wrote in 1968 - has five basic functions: diagnostic, apologetic, unmasking, theoretical, and social engineering. To pursue sociology, it is thus necessary to have a strong theoretical background, a capacity for critical analysis, reflexivity, but also to participate in the creation or transformation of social reality. 
Tilbury and Wortman (2004) mentioned most of these competences when they described what they consider key abilities which students should acquire during the process of sustainable education. The list is as follows:

- the ability to create visions - being able to imagine the future, assuming that if we know where we want to go, we will find it easier to plan how to get there;

- critical thinking and reflection - the ability to question the current belief system and to recognize the assumptions of knowledge, perspectives and opinions. This ability should facilitate learning how to study social structures, as well as environmental (local), economic and cultural ones, in the context of sustainable development;

- systems thinking - the ability to understand and seek links and synergism during problem-solving;

- the ability to build partnerships, promote dialogue and negotiations - being able to cooperate;

- involvement in the decision process - "empowering people".

Therefore, while we claim these abilities can be gained by multiple forms of teaching, the first step is to prepare new generations for training some social skills and competences that are useful with "real people" in real situations.

As Sterling and Maxey (2013) have emphasized, the discourse on sustainability is marked by a clear conviction that universities should not only be agents of change, but also undergo changes themselves. These authors distinguish two areas of learning: planned and institutional. The first one encompasses students, whereas the second one includes academic and administrative university staff, as well as decision makers. Underlying this approach is the assumption that effective sustainable education at the university level is possible only when the university itself becomes more sustainable. Such a university 
“(...) embodies, critically explores and lives sustainability" (Sterling, Maxey 2013, p. 7).

Also significant in this context are the assumptions adopted regarding the effects of ESD. If the goal is to strengthen and encourage students to think critically and be committed, neoliberal demands on the function of universities appear highly inadequate. Moreover, universities reduced to the role of vocational schools are not only unable to achieve the objectives of this type of education, but also lose the qualities inherent in their modern conception, which is the culmination of the European path of searching for their modern formula (cf. Pluciński 2013).

The latter - which is consistent with the discussed concept of ESD treats the development of students as mature, independently thinking individuals as absolutely fundamental. These goals are linked to the significant position which the university has occupied in the emancipatory project of modernity from the very beginning: "The autonomy of reason, cultivating knowledge and incessant self-criticism were supposed to give it a power to change the social world and make it a better place for all people" (Gdula 2010, p. 218).

In our view the concept of ESD is based on a unique conception of the individual human being. The postulate here is to view humans from a holistic or realistic perspective, taking into account their embedding in a specific context, in contrast to the simplified and limited view of the individual proposed by liberal theory ${ }^{10}$. The student's role is not limited to the role of a consumer of the educational services, nor are students

\footnotetext{
${ }^{10}$ Among the scholars who pointed out the limitations of the liberal conception of the individual human being were authors belonging to the communitarian trend. As Śpiewak (2004, p. 12) wrote in an analysis of communitarian thought, according to its creators “(...) the liberal hero, the author of his own self and of his roles, is pure myth. (...) Thus, communitarians say that libertarians present the process of selfunderstanding and self-description in a way that is doubtful at best, and, moreover, one-sided". Importantly, emphasizing the embeddedness of the individual human being in various contexts is particularly attractive from the perspective of sociology, since the scope of this science includes theories that conceptualize the individual human being as embedded not only in a social network, but also in a network composed of non-human actors.
} 
prepared for such a role. The teacher's role is to build a capacity to be able to approach the broad, complex nature of sustainability, the problem-oriented attitude and the partnership in teaching students being responsible citizens (Warren et al. 2014).

These assumptions have consequences in the form of the postulated content and forms of education. On the one hand, sustainability in education means that students are taught not only knowledge but also values that support sustainable development (in a broad sense); on the other hand, they are also taught values that strengthen selfdetermination in the face of an established hegemony of power (Kopnina 2014, p. 103). ESD is a proper way to prepare generation $R$ for a better understanding of social worlds, creative thinking as well active participation in the processes of changes that inevitably must come.

It must also be emphasized that, as Helen Kopnina (2014) wrote, the modern conceptualization of education as discussed here tends to increasingly stress the need to implement an open approach to education, rather than the importance of developing particular abilities, knowledge or attitudes.

Thus, the utilized educational methods enable learners to respond appropriately to diversity and transcend their own horizons. The importance of pluralism as an educational tool is also emphasized, since it not only informs peopleabout significant alternatives to the dominant neo-liberal model, but also creates a unique opportunity for their critical study and debate about them (Kopnina 2014, p. 102). We believe that academic teachers are now increasingly aware of the open idea of education - no matter whether it is presented under ESD framework or "classical" critical thinking. 
Conclusions

In our opinion the conclusions drawn from recommendations associated with the idea of ESD, as well as with the above-mentioned concept of the individual as an agent and, more broadly, with the process of social change/ reproduction, have fundamental significance for the education process. We ascribe particular importance to reflection on the role of theindividual (subject) in the education process and on specific education methods.

During the implementation of various teaching methods, treating the human condition or human nature as imbued with agency creates many opportunities, but also potential risks. Among other things, the dialogical form of the education process is important here, as we mentioned earlier in the context of Burawoy's concept (2009).

We also claim that it is necessary to draw attention to the special characteristics of ESD and sociology teaching processes. The results presented here might be viewed in light of their methodological limitations (one field research qualitative case study), however we assume, they are showing useful insights and ideas for planning the curriculum not only in sociology or the humanities and social sciences but broadly in interdisciplinary modules. Apart from discussions about the university and academics' roles and university crisis, we are strongly convinced that involving students in field research (whether within PAR paradigm or not) is an efficient way to implement the ESD into academic teaching.

Utilizing the methods recommended by Burawoy definitely broadens the context of education itself, and the ESD framework stresses the empowerment of people to prepare them for responsible actions. Hence, the shifts in education should beassociated with a sense of responsibility for our own actions (as academic teachers, researchers, 
students and so on), partnership and responsibility to tackle and understand systemic consequences on the local and global level.

We wish to acknowledge the help during the project and cooperation in the previous versions of this text provided by Anna Radiukiewicz. Her feedback on this article during various stages of its development was a great inspiration for us. We would like to express our gratitude to Krzysztof Polewski, the director of GOK in Mykanów, who envisioned the usefulness of our cooperation and was always very hospitable and creative in solving problems. We appreciate the inhabitants of the municipality for their time and support in this project. We also thank all the students for their commitment in conducting the research. Any errors or inconsistencies remain our own.

Katarzyna Iwińska \& Marta Sałkowska

References

Archer M. (1995), Realist Social Theory: The Morphogenetic Approach, Cambridge, Cambridge University Press

Ayers J. (2011), The Sustainability Revolution: A scientific analysis of beneficial changes for societies, communities and individuals. http:// www.vanderbilt.edu/Sustainability/ book/S1C1_ handout.pdf [May 15, 2016]

Ball S.J . (2012), Performativity, commodification and commitment: An I-spy guide to the neoliberal university, "British Journal of Educational Studies" Vol. 60 (1)

Barrett R. (2011), On Students as Customers: Contesting the Analogy, "Higher Education Review", Vol. 43 (2)

Berger P.L., Luckman T. (1983), Spoleczne tworzenie rzeczywistości, Warszawa, Państwowy Instytut Wydawniczy

Burns T.R. (2012), Sustainable development: sociological perspectives, sociopedia.isa, http:// www.sagepub.net/isa/resources/pdf/Sustainab leDevelopment.pdf [November 12 2019]

Bourdieu P. (1990), The logic of practice, Cambridge, Polity Press

Burawoy M. (2004), For Public Sociology. 2004 Presidential Address, http:// burawoy.berkeley.edu/Public\%20Sociology,\%20Live/ Buraw oy.pdf [J une 1, 2016] 
Burawoy M. (2009), Challenges for a Global Sociology, "Context" Vol. 8, Iss. 4, https:/ / doi.org/ 10.1525/ ctx.2009.8.4.36

Burawoy M. (2012), The public university - a battleground for real utopias, http:// burawoy.berkeley.edu/Universities/The\%20Public \%20University\%20as\%20Real\%20utopia.pdf [May 15, 2016]

Činčera J., Aspengren P. (2018), Sustainability and an educational perspective: roots in environmental education, [in:] Widening Interdisciplinary Sustainability Education, (Eds.) Iwińska K., J ones M., Kraszewska M., Warsaw, Collegium Civitas

Činčera J., Mikusiński G., Binka B., Calafate L., Calheiros C., Cardoso A., Hedblom M., J ones M.; Koutsouris A., Vasconcelos C., Imińska K. (2019), Managing Diversity: The Challenges of Inter-University

Cooperation in Sustainability Education, "Sustainability", Vol. 11 (20), 5610, https:// doi.org/ 10.3390/ su11205610

Cuthbert R. (2010), Students as customers?, "Higher Education Review"Vol. 42 (3)

Czerepaniak-Walczak M. (2013), Wprowadzenie, [in:] Fabryki dyplomów czy universitas?, (Ed.) Czerepaniak-Walczak M., Kraków, Oficyna Wydawnicza Impuls

Edwards A.R. (2005), The Sustainability Revolution: Portrait of a Paradigm Shift, Gabriola, New Society Publishers

Freire P. (2005), Pedagogy of the oppressed, London, The Continuum International Publishing Group

Gdula M. (2010), Wtadza krytyczna i sila wyobraźni, [in:] Uniwersytet zaangażowany. Przewodnik Krytyki Politycznej, Warszawa, Wydawnictwo Krytyki Politycznej

Giddens A. (2003), Stanowienie spoleczeństwa. Zarys teorii strukturacji, Poznań, Zysk i S-ka

Greenwood D.J. (2012), Action research, czyli o badaniach $w$ dziataniu, [in:] Badania jakościowe. Podejścia i teorie, (Ed.) J emielniak D., Warszawa, Wydawnictwo Naukowe PWN 
Gruenewald D.A. (2008), The best of both worlds: a critical pedagogy of place, "Educational Researcher", Vol. 32(4), http:// doi.org/ 10.1080 / 13504620802193572

Henebery B. (2019), Italy makes climate change education mandatory, "The Educator Magazine", https:// www.theeducatoron line.com/k12/news/italy-makes-climate-change-education-mandatory/ 267953 [February 3, 2020]

Horyń W., Maciejewski J. (2007), Andragogika w ujęciu interdyscyplinarnym, Wrocław, Wydawnictwo Uniwersytetu Wrocławskiego

Iwińska K., Jones M. (2018), Sustainability and social dimensions of planning, [in:] Widening Interdisciplinary Sustainability Education, (Eds.) Iwińska K., J ones M., Kraszewska M., Warsaw, Collegium Civitas Kopnina H. (2014), Neoliberalism, pluralism, environment and education for sustainability, "Horizons of Holistic Education", Vol. 1 Kopnina H., CherniakB. (2016), Neoliberalism and justice in education for sustainable development: a call for inclusive pluralism, "Environmental Education Research" Vol. 22 (6)

Lewin K. (1946), Resolving Social Conflicts, New York, Harper and Brothers Publishers

Lewin K. (2010), Badania $w$ działaniu a problemy mniejszości, [in:] Badania $w$ działaniu. Pedagogika $i$ antropologia zaangażowane (Eds.) Cervinkova H., Gołębniak B.D., Wrocław, Wydawnictwo Naukowe Dolnośląskiej Szkoły Wyższej

Loeber A. (2004), Practical wisdom in the risk society. Methods and practice of interpretive analysis on questions of sustainable development, $\mathrm{PhD}$ thesis, Amsterdam, University of Amsterdam Loeber A., Mierlo B. van, Leeuwis C., Grin J . (2007), The practical value of theory: conceptualizing learning in the pursuit of a sustainable development, [in:] Social Learning toward a more Sustainable World: Principles, Perspectives, and Praxis, (Eds.) Wals A., Leij T. van der, Wageningen, Wageningen Academic Publishers 
MoCrindle M. (2003), Understanding Generation $Y$, "Principal Matters" No. 55

Miller B. (2010), Skills for sale: what is being commodified in higher education?, "J ournal of Further and Higher Education" Vol. 34 (2)

Mills C.W. (2007), Wyobraźnia socjologiczna, Warszawa, Wydawnictwo Naukowe PWN

Mueller M.P. et al. (2014), Introducing Generation R, [in:] Assessing Schools for Generation $R$ (Responsibility), (Eds.) Mueller M.P., Tippins D.J., Stewart A.J . (Eds.), Basel, Springer Nature OECD (2011), Divided We Stand: Why Inequality Keeps Rising, https:/ / www.oecd.org/ els/ soc/49170768.pdf

OECD (2015), In It Together: Why Less Inequality Benefits All, OECD

Publishing, Paris, https:/ / doi.org/ 10.1787/9789264235120-en

Pluciński P. (2006), Idea(t) i rzeczywistość uniwersytetu. Diagnoza neoklasyczna, „Nowa Krytyka” Vol. 19

Podgórecki A. (1968), Pięć funkcji socjologii, [in:] Socjotechnika. Praktyczne zastosowania socjologii, Warszawa, Książka i Wiedza Rieckmann M. (2011), Key Competencies for a Sustainable Development of the World Society. Results of a Delphi Study in Europe and Latin America, "GAIA - Ecological Perspectives on Science and Society" Vol. 20 (1)

Rittel H.W.J., Webber M.M. (1973), Dilemmas in a general theory of planning, "Policy Sci” Vol. 4 (155), https:// doi.org/ 10.1007/BF01405730 Schäfer A. (2012), Consequences of social inequality for democracy in Western Europe, "Zeitschrift für Vergleichende Politikwissenschaft" Vol. 6, https:/ / doi.org/ 10.1007/ s12286-010-0086-6

Shumar W. (1997), College for sale: A critique of the commodification of higher education, Basingstoke, Falmer Press

Sterling S. (2014), At variance with reality: how to rethink our thinking, “J ournal of Sustainability Education”, Vol. 6, http://www.susted.com 
/ wordpress/ content/ at-variance-with-reality-how-to-re-think-ourthinking_2014_06/

Sterling S., Maxey L. (2013), Introduction, [in:] The Sustainable University. Progress and Prospects, (Eds.) Sterling S., Maxey L., Luna H., London- New York, Routledge

Stringer E. (1996), Action Research. A Handbook for Practitioners, London- New Delhi- Thousand Oaks, Sage Publications Sund P., Lysgaard J .G. (2013), Reclaim "Education" in Environmental and Sustainability Education Research, "Sustainability" Vol. 5 (4), 1598-1616, https:/ / doi.org/ 10.3390/su5041598

Szkudlarek T. (2008), Ekonomia i etyka: przemieszczenia dyskursu edukacyjnego, [in:] Pytanie o szkotę wyższa $w$ trosce o człowieczeństwo, (Ed.) Gołębniak B.D., Wrocław, Wydawnictwo Naukowe Dolnośląskiej Szkoły Wyższej

Sztompka P. (1999), Stawanie się społeczeństwa: pomiędzy struktura a zmiana, [in:] Zmiana społeczna: teorie i doświadczenia polskie, (Ed.) Kurczewska J ., Warszawa, Wydawnictwo IFiS PAN Śpiewak P. (2004) Poszukiwanie wspólnot, [in:] Komunitarianie. Wybór tekstów, (Ed.) Śpiewak P., Warszawa, Aletheia Tilbury D., Wortman D. (2004), Engaging People in Sustainability, Gland, IUCN The Commission on Education and Communication UN (1987), Our Common Future. Report of the World Commission for Environment and Development, Transmitted to the General Assembly as an Annex to document A/42/427 - Development and International Co-operation: Environment, http:// www.un-docume nts.net/ wced-ocf.htm [February 3, 2020]

UNESCO (2016), What is ESD?, http:// en.unesco.org/themes/ education-sustainable-development/what-is-esd

UNESCO (2002), Education for Sustainability - from Rio to Johannesburg: Lessons Learnt from a Decade of Commitment, https:/ / unesdoc.unesco.org/ ark:/ 48223/pf0000127100 
Wals A.E.J. (2015), Beyond unreasonable doubt. Education and learning for socio-ecological sustainability in the Anthropocene, Wageningen, Wageningen University, https://arjenwals.files. wordpress.com/2016/02/8412100972_rvb_inauguratie-wals_ oratieboekje_v02.pdf

Wals et al. (2012), Sustainable Higher Education - Understanding and Moving Forward, Brussels, Flemish Government - Environment, Nature and Energy Department

Warren A., Archambault L., Foley R.W. (2014), Sustainability Education Framework for teachers: developing sustainability literacy through futures, values, systems, and strategic thinking, "The Journal of Sustainability Education” Vol. 6, http:// www.jsedimensions.org/ word press/ wp-content/ uploads/ 2015/ 01/Warren-et-al.-J SE-May-2014 -With-Hyperlinks-Rider-corrected.pdf

Weinstein-Fitzgerald K. (1999), Action learning, Warszawa, Petit

Wiek A., Withycombe L. Redman C.L. (2011), Key competencies in sustainability: a reference framework for academic program development, "Sustain Sci" Vol. 6 (2030, https:// doi.org/ 10.1007/ s11625-011-0132-6

Willmott H.Ch. (1995), Managing the Academics: Commodification and Control in the Development of University Education in the U.K, “Human Relations” Vol. 48 (9), DOI: 10.1177/001872679504800902 Wroczyńska A. (2013), Oczekiwania współczesnych studentów wobec uczelni wyższych - prezentacja wyników prowadzonych badań „Studia BAS”, No. 3 (35)

Wyka A. (2004), Metodologiczny casus badań poprzez wspótprace [in:] (Eds.) Kempny M., Kiciński K., Zakrzewska E., Od kontestacji do konsumpcji. Szkice o przeobrażeniach współczesnej kultury, Warszawa, Instytut Stosowanych Nauk Społecznych Uniwersytetu Warszawskiego 